\begin{tabular}{|c|c|c|}
\hline $\begin{array}{c}\text { Degree of Nematodes Worm Infection in } \\
\text { Pelagic Fish Populations from the } \\
\text { Romanian Black Sea Waters }\end{array}$ & $\begin{array}{c}\text { "Cercetări Marine“ } \\
\text { Issue no. 51 }\end{array}$ & \\
$\begin{array}{c}\text { (Aurelia Țoțoiu, Victor Niță, Valeria Abaza, } \\
\text { George Emanuel Harcotă, Elena Bișinicu, } \\
\text { Victor Cristea) }\end{array}$ & Pages $\mathbf{1 4 0}-\mathbf{1 5 5}$ & $\mathbf{2 0 2 1}$ \\
\hline \multicolumn{2}{|c}{ DOI:10.55268/CM.2021.51.140 } \\
\hline
\end{tabular}

\title{
DEGREE OF NEMATODES WORM INFECTION IN PELAGIC FISH POPULATIONS FROM THE ROMANIAN BLACK SEA WATERS
}

\section{Aurelia Țoțoiu ${ }^{1}$, Victor Niță ${ }^{1}$, Valeria Abaza ${ }^{1}$, George Emanuel Harcotă ${ }^{1}$, Elena Bișinicu ${ }^{1}$, Victor Cristea $^{2}$}

${ }^{1}$ National Institute for Marine Research and Development "Grigore Antipa", 300 Mamaia Blvd, 900581, Constanta, Romania

${ }^{2}$ Dunărea de Jos" University of Galati, Cross-Border Faculty of Humanities, Economics and Engineering, 47, Domneasca Str., 800008, Galati, Romania E-mail:atotoiu@alpha.rmri.ro

\begin{abstract}
Pelagic fish species can be affected by a series of infectious and parasitic diseases. The data used for this study are represented by the biological material collected between 2018 and 2019, from trap nets along the Romanian Black Sea waters. To establish the degree of parasitism, the following species of pelagic fish were studied: Sprattus spratus -sprat, Engraulis encrasicholus - anchovy and Trachurus mediterraneus- horse mackerel. Four species of endoparasites were identified, belonging to nematodes, as follows: Hysterothylacium aduncum, Contracaecum sp., Porrocaecumsp. and Anisakis sp. The parasites, especially found as larvae, more in free state and less trapped in the internal organs, infested the abdominal cavity, leading to degenerations, atrophies and reduction of the fish functions. The intensity of the parasitism infestation could be lethal, the size of the stocks being severely damaged. At the analysed fish species, the infestation degree was under 20 parasites per host, a low number of species recording the maximum value of 40 parasites per host. The parasites tend to accumulate with the increase of the fish's size, young stages being less affected.
\end{abstract}

Key-Words: parasites, fish, nematodes, intensity, infestation degree

\section{AIMS AND BACKGROUND}

In natural marine ecosystems, fish become infested with parasites in their places of agglomeration which are formed with the aim of feeding, reproduction or wintering. Parasitization of fish can be done by adult parasites or by their larval forms such as ciliated protozoa, monogenes, crustaceans, trematode larvae which during their movements directly attack the fish. 
One of the main characteristics of parasites is the complexity of their life cycle strategies, involving one, two or more consecutive hosts and alternating between vertebrate and invertebrate hosts in the marine environment.

Nematoda worms are components of marine ecosystems and communities. In natural marine ecosystems, individuals are often co-infected with many species of parasites. However, the significance of the interactions between species and the processes that shape the parasite-host communities remain unclear to specialists. Studies on parasite communities' ecology are often descriptive, focusing on models for determining the abundance of parasites among host populations, less on the mechanisms underlying interactions in the host organism. These interactions that take place in the host organism are crucial for determining their impact and transmission pathways (Pedersen et al., 2006). Most hosts are probably infected or sequentially infected with several species of parasites, the interactions between them occurring frequently. These interactions can be synergistic or antagonistic and are mediated by direct competition for resources or indirect competition through host immune responses (Graham et al., 2007).

Parasites have been successfully used as tools to understand several aspects of host biology, namely, identification and impact on fish stocks (Santos et al., 2009), population structure (Larsen et al., 1997) and clarification of taxonomic relationships (Luque et al., 2008). Increased availability of food resources may potentiate the immune defense mechanisms against parasitic infection (Lafferty et al., 2003).

\section{EXPERIMENTAL}

In order to evaluate the parasitism degree of pelagic fish species which are of commercial interest on the Romanian coast, the latest available data was used.The biological material was collected by NIMRD experts from trap nets located in Vadu, Năvodari, Agigea, Eforie Sud, Costinești and VamaVeche (Fig. 1, Fig. 2). Samples were collected between May and October 2018 2019, bimonthly, the analysis being performed in the ichthyopathology laboratory.

To determine the degree of parasitism, the following species of pelagic fish were studied: Sprattus spratus Linnaeus, 1758 - sprat, Engraulis encrasicholus Linnaeus, 1758) - anchovy and Trachurus mediterraneus (Steindachner, 1868) - horse mackerel.

In order to evaluate the effects of nematodes (cylindrical worms) on fish, it is necessary the parasitological analyzes to be performed on as many specimens as possible. For this reason, the species for which the analyzes could be performed on at least 50 specimens were chosen. According to the latest data from the literature, the analyzed elements include: 
- prevalence - percentage of infested fish;

- average intensity - average number of parasites/infested host; and uninfested.

- abundance - average number of parasites/total fish analyzed - infested

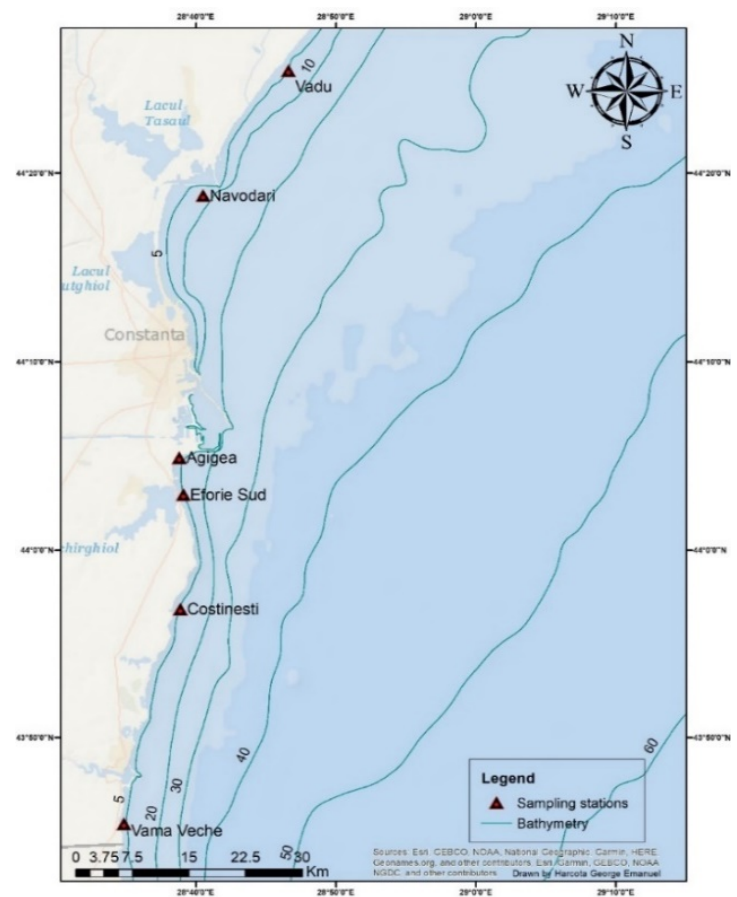

Fig. 1. Sampling location (trap nets)

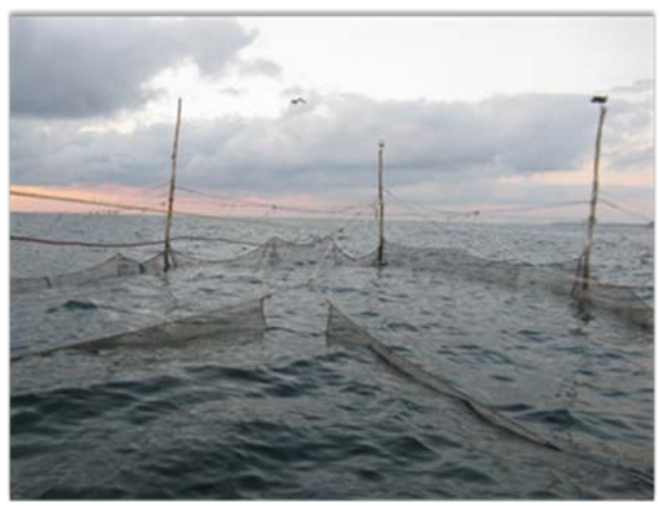

Fig. 2. Trap nets in the Romanian Black Sea

To determine the degree of parasitism of pelagic marine fish, macroscopic and microscopic examinations were performed, following both the identification of the parasite and the reactions they can cause on the hosts (Amlacher, 1981).

The macroscopic examination was performed to identify parasites and the changes produced by them on the hosts, with the naked eye and a very strong magnifying glass, observing the body surface, eyes, gills. With the help of scissors, the fish was sectioned on the abdomen, carefully so as not to damage the internal organs, macroscopically observing each organ separately, then the microscopic examination was performed.

For the microscopic examination, which is of great value in the diagnosis of parasitosis, the samples were taken directly from fresh or defrosted fish (in the case of frozen samples) and consisted of: 
- scraped preparations - meaning scraped material with a scalpel on the surface of the area to be examined, usually gills, skin, intestinal mucosa and placed on the blade;

- crushed preparations (squashes) - consisting of small portions of tissues and organs, crushed between the blade and the lamella.

PRIMER 7 program was used for the processing and statistical analysis of the obtained data and the ArcGIS 10.5 program provided the distribution maps.

\section{RESULTS AND DISCUSSION}

Pelagic fish are the most abundant fish species in the Black Sea. The three species selected for the study were anchovy, sprat and horse mackerel.

Anchovy plays a crucial role in the pelagic trophic chain of the Black Sea, being a source of food for many predators, such as bonito, bluefish, horse mackerel, dolphins, etc. Anchovies are also an important consumer of zooplankton, thus acting as a competitor to other planktonophages.

Sprat, the second pelagic species and the most crucial in terms of abundance and commercial importance in the Black Sea, serves as a major source of food for larger fish. It is found throughout the Black Sea, but the maximum abundance occurs in the northwestern region. In the spring, shoals migrate to the coastal waters for food. In summer, the sprat remains under the seasonal thermocline, forming dense groups towards the water bottom during the day and in the surface layer during the night.

The horse mackerel is a migratory species found everywhere in the Black Sea. It reaches maturity at 1-2 years in summer, which is also the main feeding and growing season. It breeds in surface waters, both offshore and near the coast.

Pelagic species in Romanian marine waters can be affected by a series of infectious and parasitic diseases. Parasitic diseases are caused by parasites of animal origin - protozoa, worms and crustaceans, the sources of these diseases being diseased fish, living marine resources carrying parasites or their corpses.

The severity of parasitic diseases is dependent on one hand on parasites (type and degree of adaptation to parasitism, their number and speed of multiplication), and on the other hand on hosts (constitution and predisposition to parasitism, ethology, etc.). In the presence of parasitosis, the environmental conditions, large agglomerations, food and migrations that can act on both agents and hosts are also of great importance (Anderson et al., 1982; Sinderman, 1987).

Parasitic diseases occur only in environmental conditions that allow the multiplication of parasites and in habitats that favor the transmission of parasites and the persistence of carriers or hosts (Bagge et al., 2004). 
Research in the field of parasitofauna of marine fish has taken a special scale, parasites being used as biological markers and as important indicators for the study of fish movement, migration and assessment of natural stocks, parasites being one of the main causes for fish populations decrease (Mac Kenzie et al. 1998; Lester, 2010).

The ichthyofauna from the Romanian coast has registered great changes, by diminishing the stocks, the catches, the reduction and the seldom appearance of some non-commercial fish species in collected samples (Radu et al., 2013). Following these observations, it was considered that the approach to research on the marine fish parasitofauna is appropriate, in order to obtain data that could help explain these phenomena.

Following the investigations, four species of endoparasites were identified, belonging to nematodes: Hysterothylacium aduncum (Rudolphi, 1802) (Contracaecum aduncum), Contracaecum sp. Railliet and Henry, 1912, Porrocaecum sp. Railet et Henry, 1912 and Anisakis sp. Dujardin, 1845 (Fig. 3).

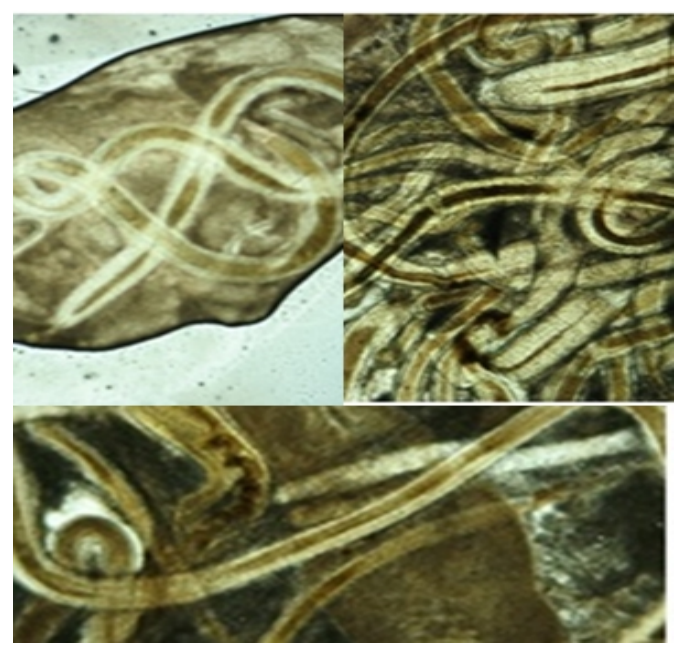

Fig. 3. Nematodes identified at fish species

Hysterothylacium aduncum parasitizes the viscera, living encapsulated or free in the abdominal cavity, intestine, pyloric appendix and fish liver. At older fish there is an accumulation of larvae, so they can reach up to a few hundred / host.

Porocaecum sp. larvae, are located in the muscles near the abdominal cavity of fish, the fish size increasing the number of parasites.

Anisakis sp. larvae, immobile nematode worms, parasitize encapsulated in the liver, pyloric and/or mobile appendages, migrating to various organs of the body, muscles, gonad. 
These parasites cause damage especially for the liver, but they also affect the reproductive organs and the digestive tract. In weak invasions, fish tolerate parasitism, the only effect being the slowdown of the fish growth rate. Severe infestations, when the number of nematodes is over 100 specimens/ host, can lead to massive destruction of parasitic organs, severe liver disease, hemorrhage, weight loss and fish death.

Between 2018 and 2019, all four nematode species were reported in the analyzed sprat population. The value of the average parasitic intensity varied from one year to another, the highest degree of parasitism was reported in 2019, in the Eforie South station with the nematode worm Contracaecum $s p$. The presence of the nematode Anisakis sp. was highlighted during the whole analyzed period, with lower intensities (Fig. 4).

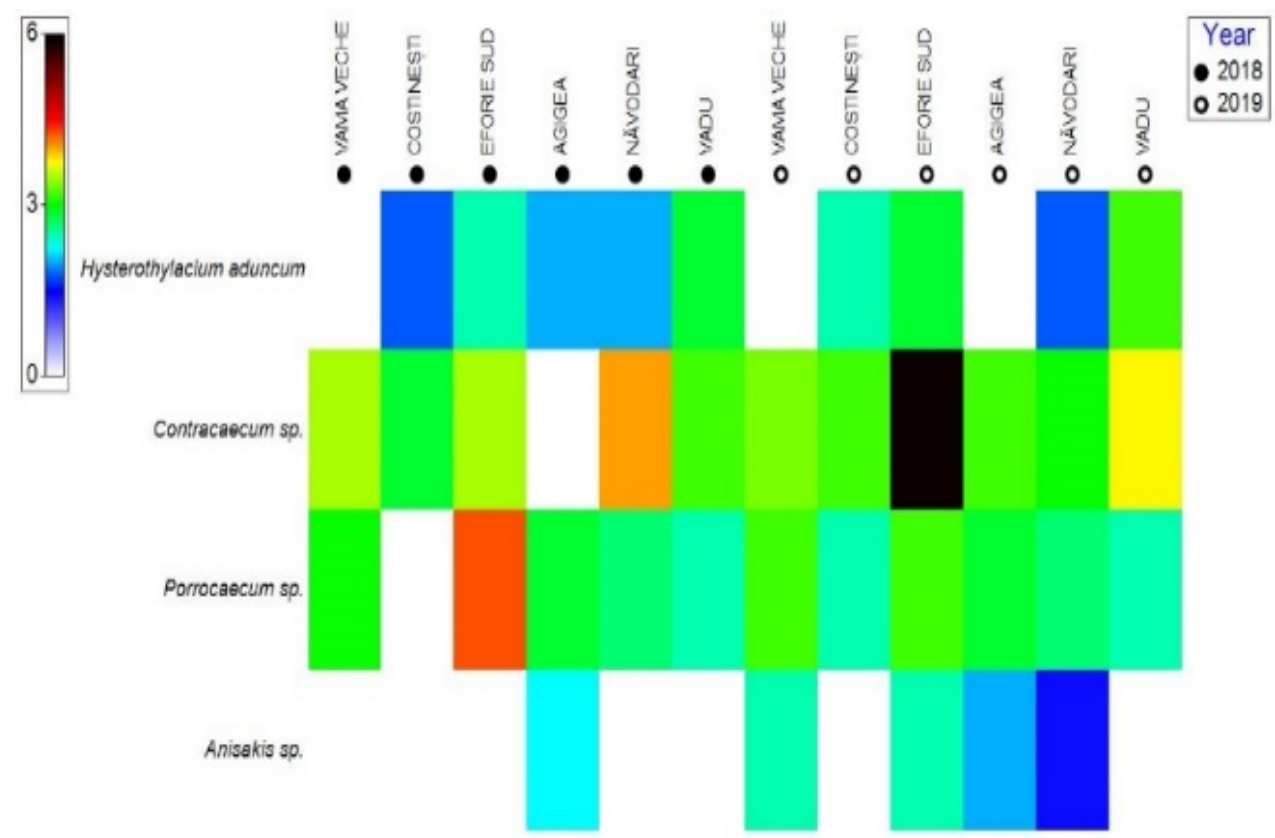

Fig. 4. Matrix of the average parasitic intensity in sprat with H. aduncum, Contracaecum sp., Porrocaecum sp., Anisakis sp., in 2018 - 2019 (square root transformed)

The abundance reported in sprat was lower for fish smaller than $7-8$ $\mathrm{cm}$, the values recorded being of $2-4$ parasites/fish. The highest value of abundance was recorded in sprat specimens of $10-11 \mathrm{~cm}$, respectively $6-12$ parasites/fish. The more intensely parasitic specimens showed lesions in the nematode larval trapping areas (Fig. 5).

The highest prevalence of sprat was reported in $10 \mathrm{~cm}$ length class, with values between $66-96 \%$, specimens in classes $9 \mathrm{~cm}$ and $11 \mathrm{~cm}$ with 
prevalence values of up to $77 \%$. The $7 \mathrm{~cm}$ length class was the least affected by nematode worms, respectively $22-44 \%$ (Fig. 6.).

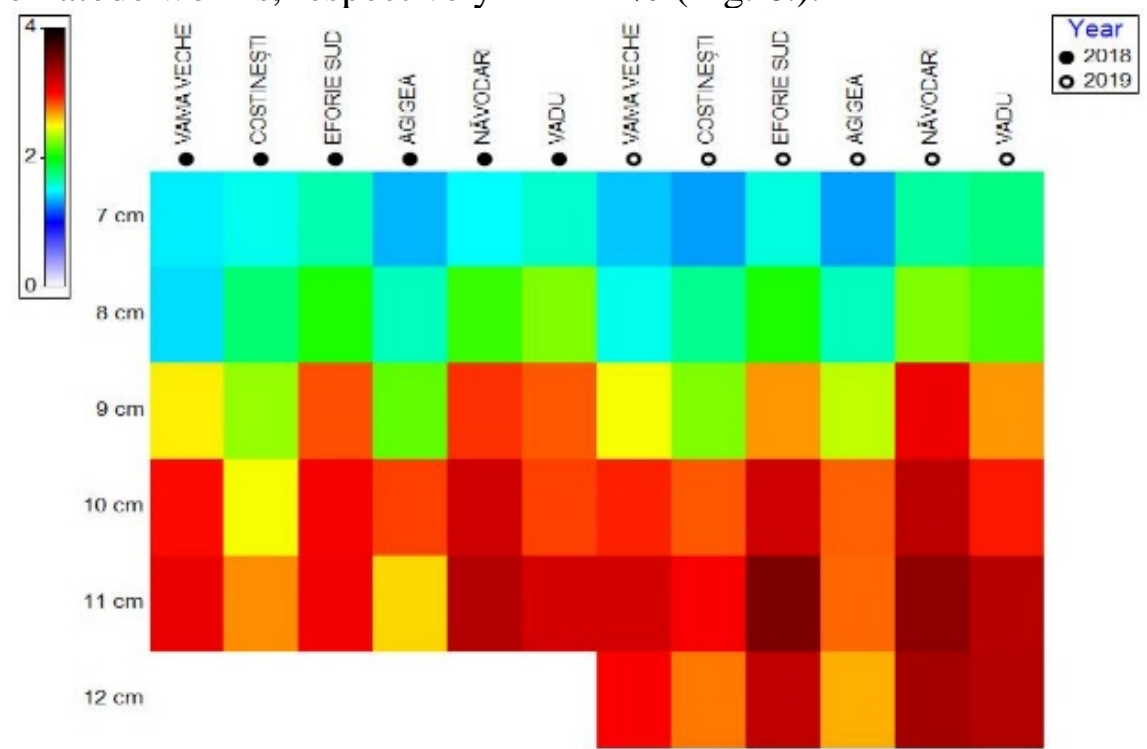

Fig. 5. Matrix of nematode abundance in sprat, in 2018 - 2019 (square root transformed)

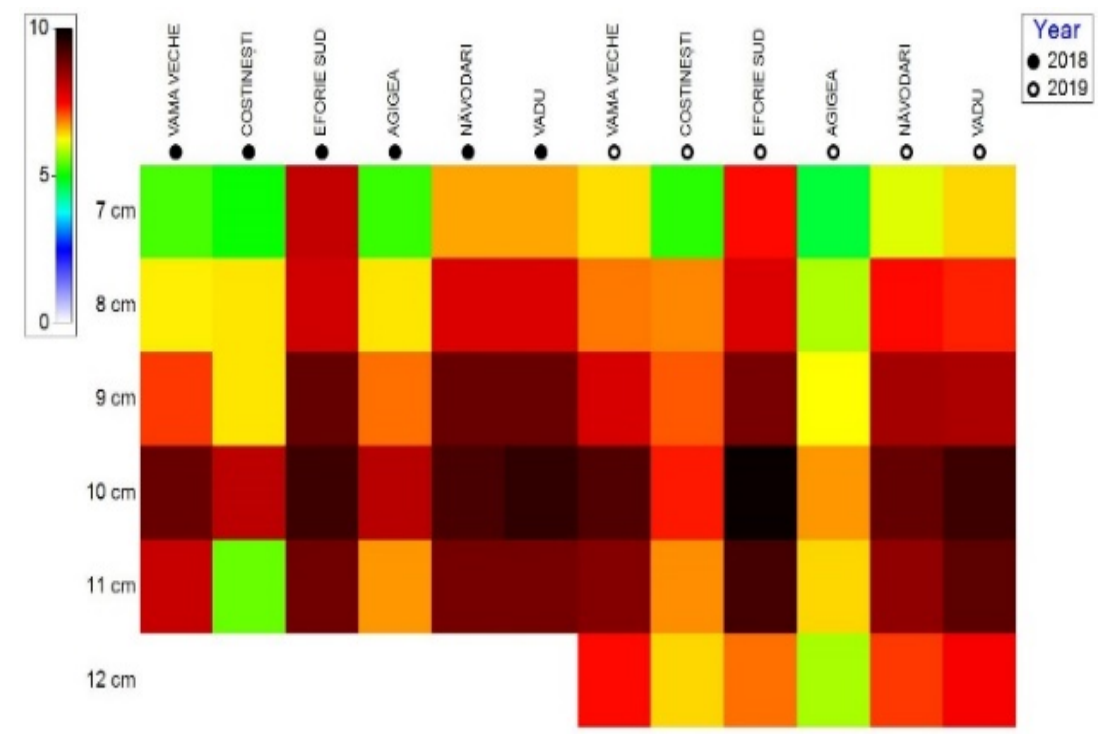

Fig. 6. Matrix of nematode prevalence in sprat, in 2018 - 2019 (square root transformed)

The average intensity of parasitism with nematodes was the highest in sprat specimens collected from Eforie South station, and the lowest number of parasites was recorded at specimens collected from Costinesti (Fig. 7). 
In the anchovy population researched between 2018 and 2019, the presence of the four species of nematode worms as in the sprat population was highlighted. The highest average parasitic intensity values were reported in 2018 and 2019, in the Eforie South station with Porrocaecum sp.

The $H$. aduncum nematode was reported throughout the studied period, both in the northern and in the southern part of the Romanian coast (2-3 stations/year) with an average parasitic intensity of 2 parasites/host (Fig. 8). The anchovy population in the six marine areas showed a tendency for nematodes to accumulate in larger specimens $(10-12 \mathrm{~cm})$. Anchovy, which was between 7 and $9 \mathrm{~cm}$ length, showed an abundance of 2 - 4 parasites / fish, the value of abundance being much higher in specimens of $11-12 \mathrm{~cm}$, reaching the maximum value of 16 parasites /fish (Fig. 9). The body of infested fish had lesions in the affected organs (liver, intestines), lack of food in the stomach.

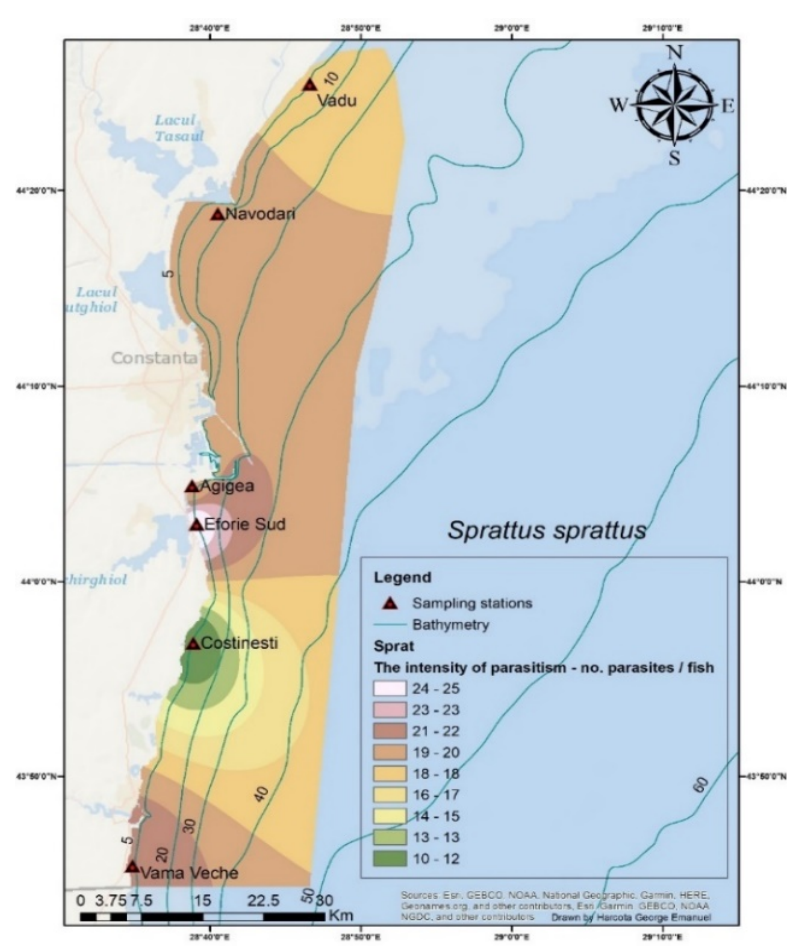

Fig. 7. Distribution of the average intensity of parasitism with nematodes in sprat, in 2018 - 2019

The prevalence of anchovies showed a high degree of parasitism between 2018 and 2019 in all six stations on the Romanian coast. The specimens of anchovy caught in the purse seines from the marine areas of Năvodari and Vadu recorded values of prevalence of 100\%, in 2019, for the length classes of $11 \mathrm{~cm}$ (Vadu) and $12 \mathrm{~cm}$ (Năvodari) and Eforie South, in 2018, for $12 \mathrm{~cm}$ length class. The high degree of parasitism in anchovy 
specimens highlighted the presence of lesions at the tissue level and the slowing down of the growth rate. The lowest prevalence values were reported in the $8 \mathrm{~cm}$ and $9 \mathrm{~cm}$ length classes, at Agigea, with values between $33-48 \%$, of the total fish studied (Fig. 10).

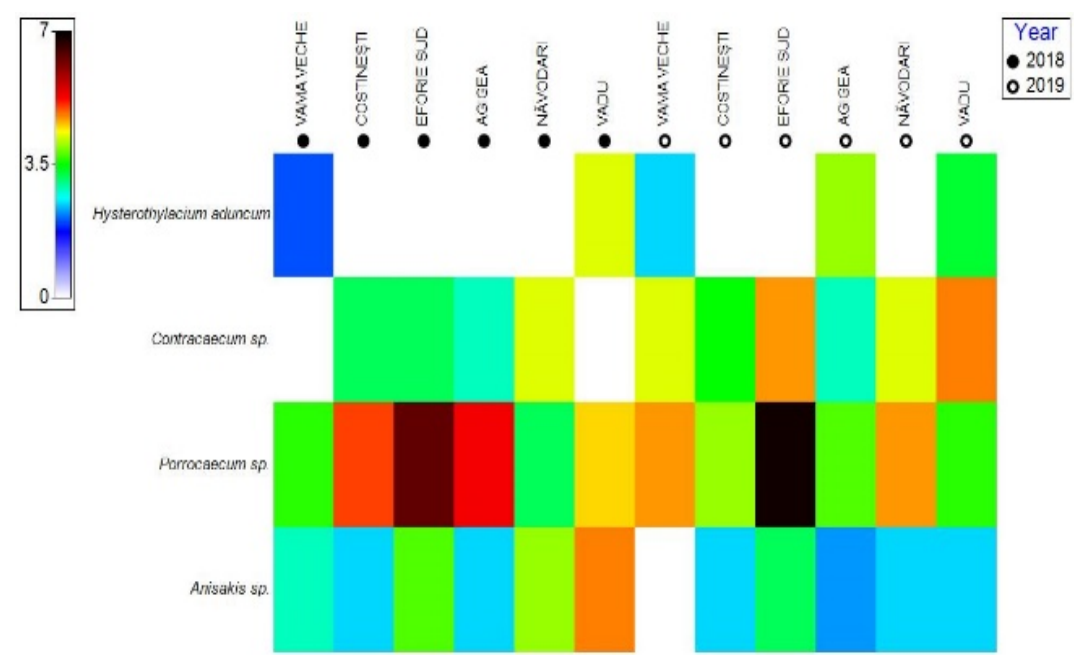

Fig. 8. Matrix of the average parasitic intensity in anchovy with H. aduncum, Contracaecum sp., Porrocaecum sp., Anisakis sp., in 2018 - 2019 (square root transformed)

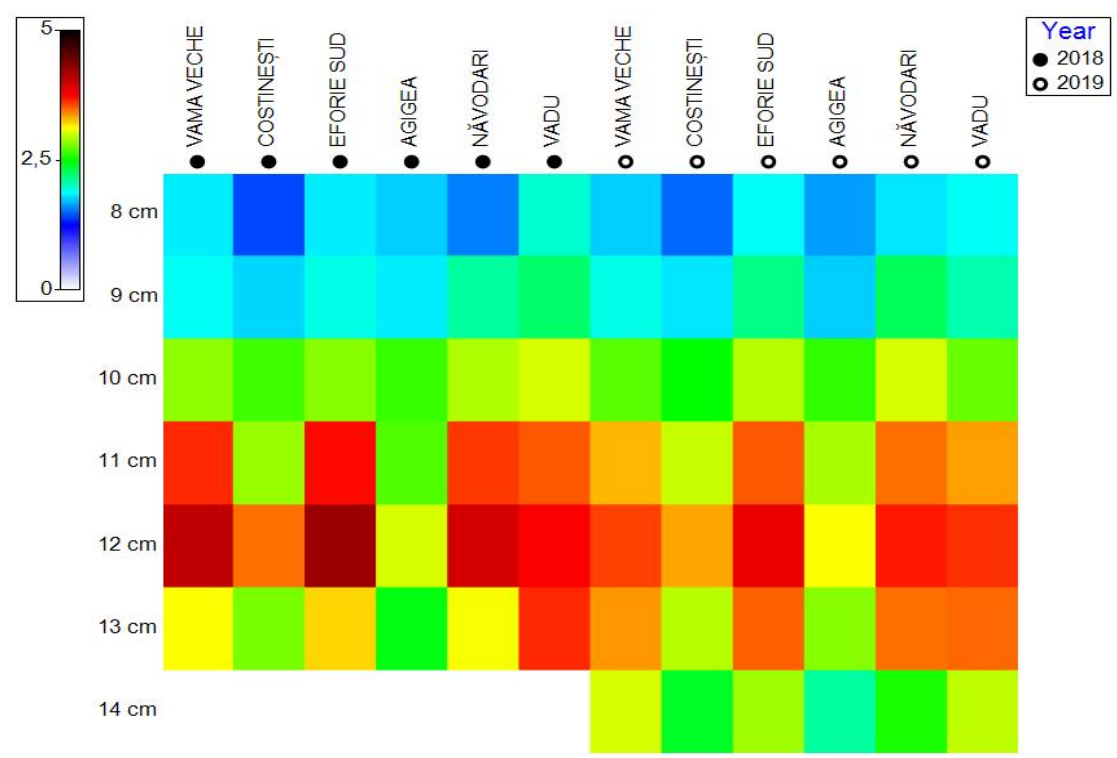

Fig. 9. Matrix of nematode abundance in anchovy, in 2018 - 2019 (square root transformed) 


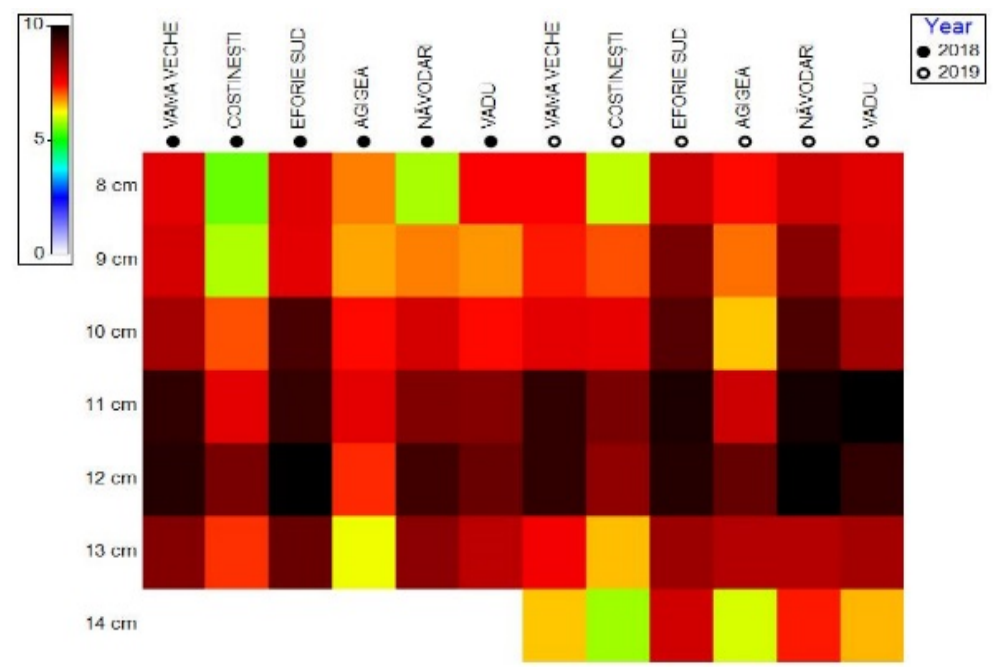

Fig. 10. Matrix of nematode prevalence in anchovy, in 2018 - 2019 (square root transformed)

Anchovy recorded the highest degree of parasitism in fish from Vama Veche area, and the lowest was reported in the fish specimens from Costinești area. In the northern part of the coast, the degree of parasitism was higher at Năvodari (Fig. 11).

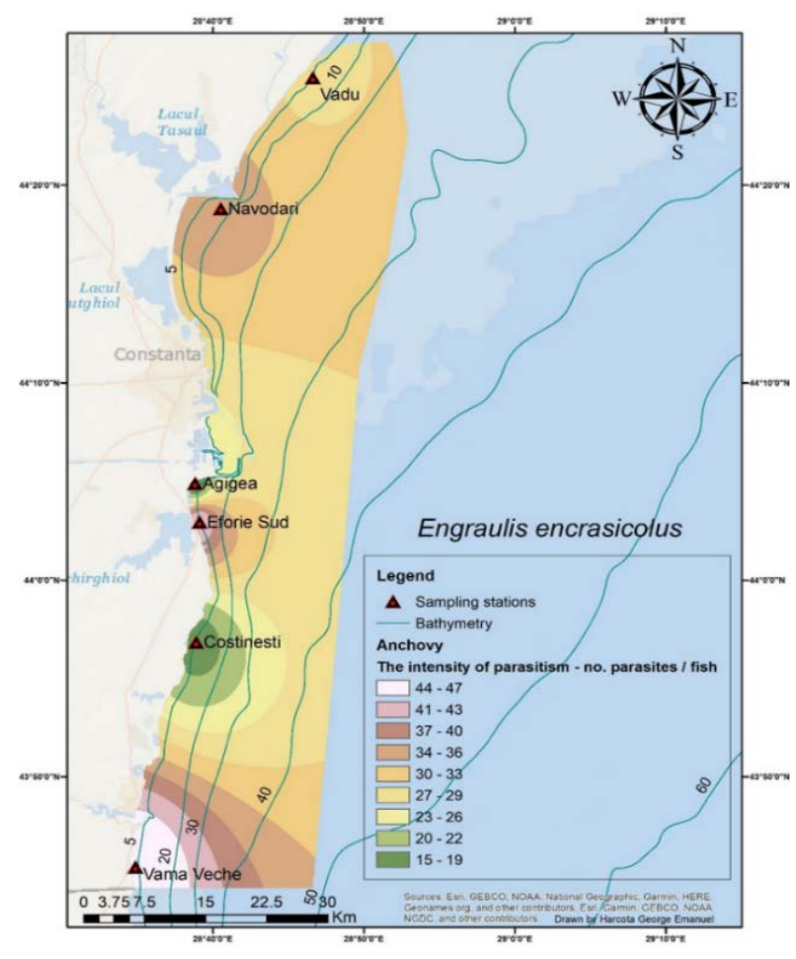

Fig. 11. Distribution of average parasitic intensity with nematodes at anchovies in $2018-2019$ 
In horse mackerel specimens analyzed between 2018 and 2019, the same nematode species were identified as in the other two fish species mentioned above. The most dominant parasite was Contracaecum sp., presenting the highest average intensity of parasitism in 2018 and 2019 (16 17 parasites/host). The nematode Anisakis sp. was identified with a lower frequency, with the highest average parasitic intensity in 2018 and 2019 (8 10 parasites/host) (Fig. 12).

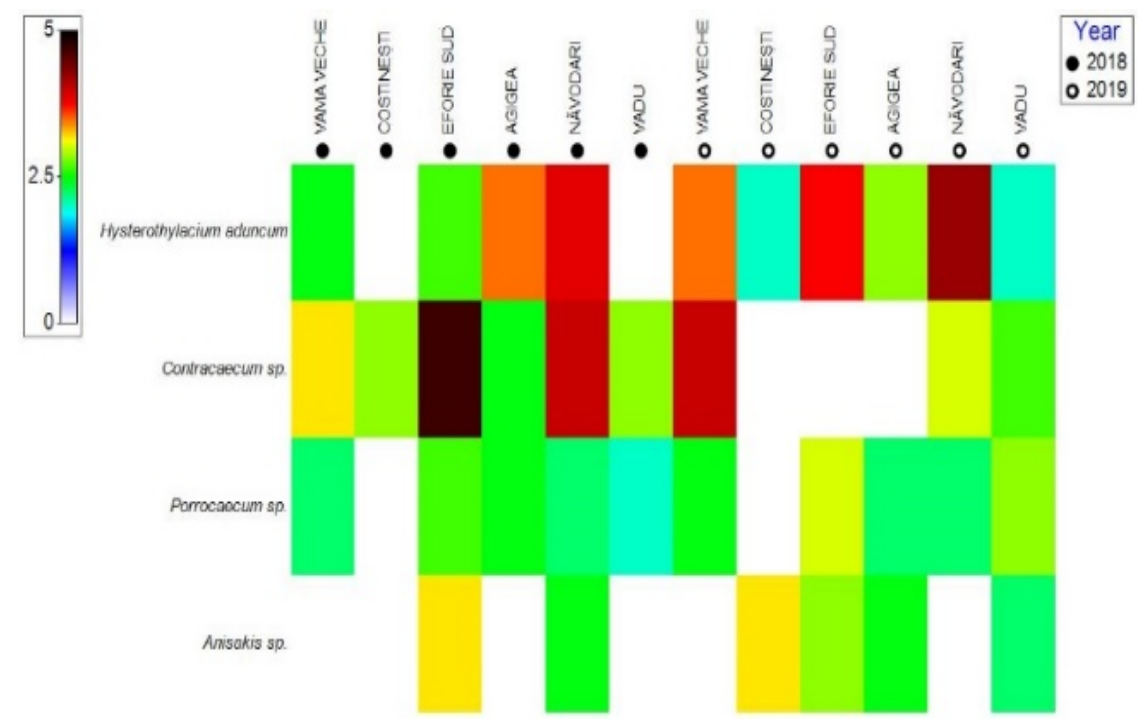

Fig. 12. Matrix of the average parasitic intensity in anchovy with H. aduncum, Contracaecum sp., Porrocaecum sp., Anisakis sp., in 2018 - 2019 (square root transformed)

The horse mackerel population showed a much lower nematodes abundance than the other two fish species (sprat and anchovy). The maximum abundance value was registered for the horse mackerel specimens belonging to $14 \mathrm{~cm}$ length class, respectively 10 parasites/fish (Năvodari). The least parasitic length classes are $11 \mathrm{~cm}$ and $12 \mathrm{~cm}$, the number of parasites being between 1 - 4 parasites / fish out of the total fish investigated (Fig. 13).

The prevalence of horse mackerel reached the maximum values for the $13 \mathrm{~cm}$ length class in all six marine areas, being between 77-97.3\%. In the affected specimens, the mechanical action of the parasites was found - injuries caused by parasites in the tissues through the fixing organs and through the movements they perform. In the matrix it can be seen that in marine areas of Costinesti and Agigea the lowest number of parasitic specimens was recorded. In the collected samples, the specimens measuring $11 \mathrm{~cm}$ and $16 \mathrm{~cm}$ dominated (Fig. 14). 


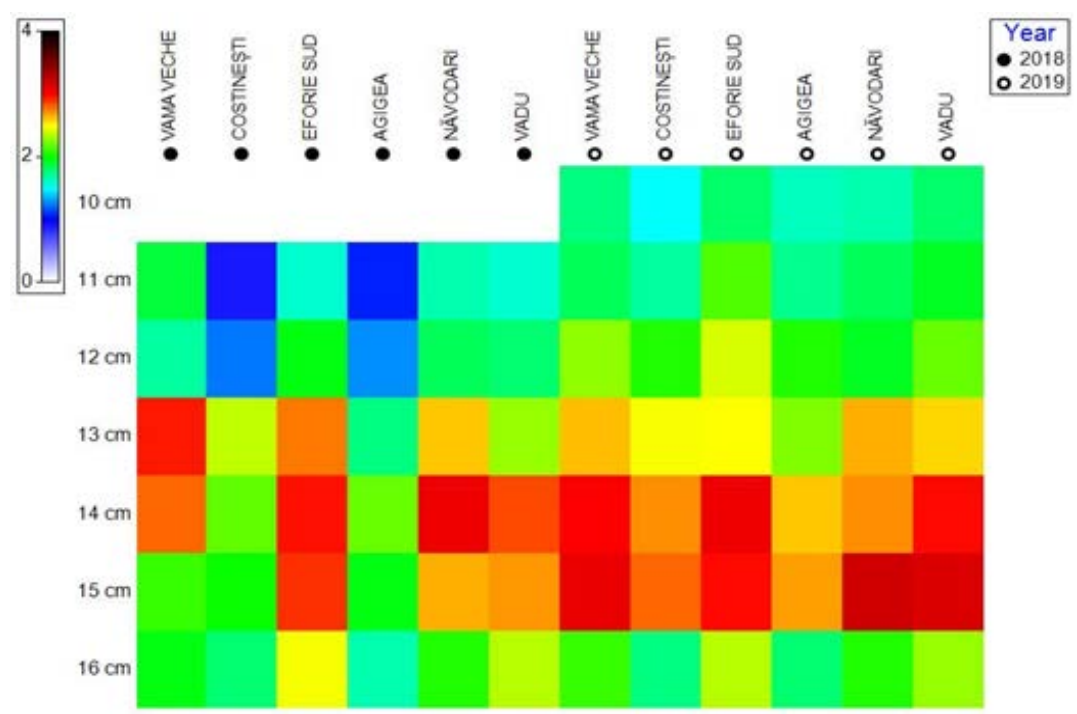

Fig. 13. Matrix of nematode abundance in horse mackerel, in 2018 - 2019 (square root transformed)

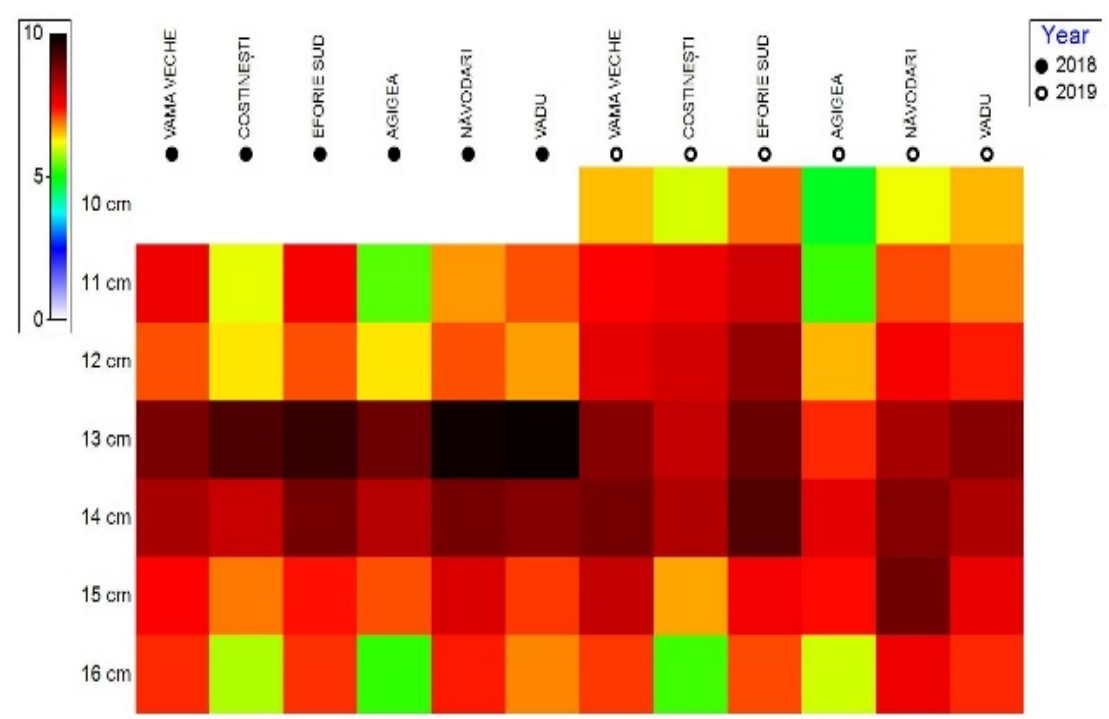

Fig. 14. Matrix of nematode prevalence in horse mackerel, in 2018 - 2019 (square root transformed)

Horse mackerel recorded the highest average intensity of parasitism in fish collected from VamaVeche area, the lowest being reported in fish specimens from Costinești and Năvodari area. In the other three studied areas, the average value of parasitic intensity varied between 19 - 25 parasites/ infested host (Fig. 15). 


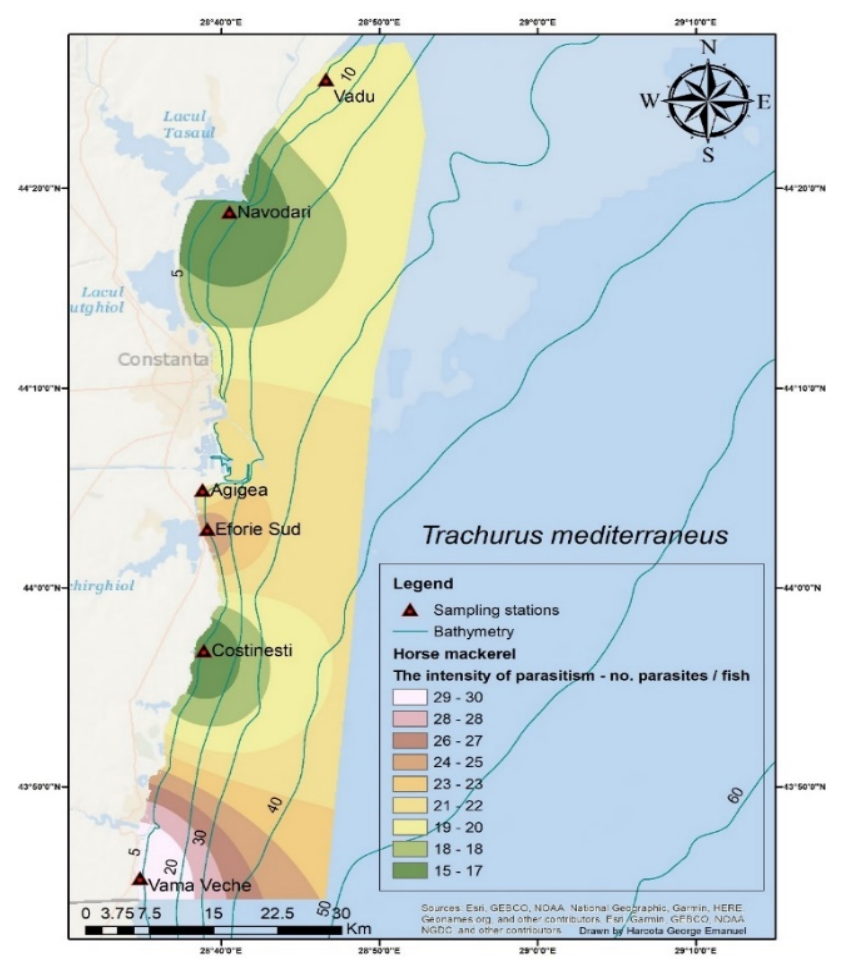

Fig. 15. Distribution of average parasitic intensity with nematodes in horse mackeel in 2018 - 2019

From the obtained results, it is observed that sprat, anchovy and horse mackerel showed a significant degree of parasitism with nematodes, belonging to Contracaecum, Porrocaecum and Anisakis genera, without posing a major danger to natural populations, for the following reasons:

- the parasites, especially in the form of larvae, infested the abdominal cavity, more in free state and less trapped in the internal organs which they can destroy especially by their mechanical action, with degenerations, atrophies and reduction of their functions;

- the small number of specimens in which the infestation intensity reached the maximum value of 40 parasites/host (in general the intensity of the parasitism being below 20 parasites/host); If the number of fish with such parasitic intensities were significant and knowing that the effects of parasitism could be lethal, the size of the stocks could have been severely damaged.

- the tendency of parasites to accumulate with the fish size increase, the younger stages being less affected.

Environmental factors, food availability, disease, pollution, and other biological elements such as parasite infections are some of the most important parameters that ultimately affect the fish health, causing an economic loss for the fish market (Ozer et al., 2015; Ferrer-Maza et al., 2016; Gücü et al., 2018). Fish populations are subject to numerous natural and anthropogenic factors that reduce their abundance (Sinderman, 2002). 
In the Black Sea, the life cycle of members of the Ascaridoidea Superfamily in their intermediate and definitive hosts are not clearly defined, it is generally known that these parasites use almost all living marine organisms, from small invertebrates to mammals, as hosts at different stages (Marcogliese, 1995). Generally, nematode eggs with developed larvae ingested by benthic and/or pelagic crustaceans hatch in their intestine and attain their haemocoel. Larger invertebrates, such as chaetognaths and crustaceans, are thought to be important second intermediate hosts and various fish species serve as paratenic or final hosts, acquiring H.aduncum through the food chain (Koie, 1993; Balbuena et al.,1998).

\section{CONCLUSIONS}

To identify the parasitofauna of marine fish, three pelagic species were analyzed, as follows: S. sprattus - sprat, E. encrasicholus - anchovy, T. mediterraneus - horse mackerel, at which four species of endoparasites were identified, all species of nematodes. Parasites can act as severe pathogens, causing direct mortality or increased vulnerability of fish to stressors (environmental and biotic).

Three species of nematodes, Hysterothylacium aduncum, Contracaecum sp., Porrocaecum sp., were present in all analysed fish species, affecting their abdominal cavity, in the free state and / or fixed on the internal organs, especially on the liver. The degree of infestation with these parasites recorded maximum values in anchovies from Vama Veche area, where the prevalence reached a maximum value of $92 \%$. Under these conditions, the organs affected by parasites have reduced functions, with disorders in terms of feeding, reproduction, and growth.

Although the number of analysed fish was quite low, some of the specific changes produced by the parasites were highlighted, if the parasitic intensities were higher than 30 parasites / host, as being relatively severe, would have led to degenerations and atrophies of the parasites. liver and bleeding lesions in the digestive tract. However, these changes have been reported in a small number of fish. If the number of fish with such parasitic intensities had been significantly higher and knowing that the effects of parasitism could be lethal, the size of the stocks would have been severely affected.

Acknowledgement: This study has been carried out with financial support from the NUCLEU INTELMAR Programme, funded by the Romanian Ministry of Education, Research and Digitization, project no. PN19260302 "The impact of limiting factors on marine living resources in the coastal zone and the improvement of stock and population parameters assessment methodologies". 


\section{REFERENCES}

Amlacher E., (1981), Taschen Buch der Fischkrankheiten, VEB Gustav Fischer Verlag Jena, 1 - 474.

Anderson R. M., Gordon D. M. (1982), Processes influencing the distribution of parasite numbers within host populations with special emphasis on parasite-induced host mortalities, Parasitology, 85:373-398. https://doi.org/10.1017/S0031182000055347

Bagge A M., Poulin R., Valtonen E. T. (2004), Fish population size, and not density, as the determining factor of parasite infection: a case study, Parasitology, 128 (3): 305-13. DOI:10.1017 / s0031182003004566

Balbuena, J. A., Karlsbakk, E., Saksvik, M., Kvenseth, A. M., \&Nylund, A. (1998), New data on the early development of Hysterothylaciumaduncum (Nematoda, Anisakidae).The Journal of parasitology, 615-617.https://doi.org/10.2307/3284732

Ferrer-Maza D., Lloret J., Munoz M., Faliex E., Vila S., Sasal P. (2016), Links between parasitism, energy reserves and fecundity of European anchovy, Engraulis encrasicolus, in the northwestern Mediterranean Sea,Conservation Physiology 4(1), cov069. https://doi.org/10.1093/conphys/cov069

Graham A. L., Cattadori I. M., Lloyd-Smith J. O., Ferrari M. J., Bjornstad O. N. (2007), Transmission consequences of coinfection: cytokines writ large, Trends in parasitology, 23(6):284-291. https://doi.org/10.1016/j.pt.2007.04.005

Gücü A.C., Genç Y., Basçınar N.S., Dağtekin M., Atılgan E., Erbay M., Akpınar I.O., Kutlu S. (2018), Inter and intra annual variation in body condition of the Black Sea Anchovy, Engraulisencrasicolusponticus potential causes and consequences, Fisheries Research 205:21-31 https://doi.org/10.1016/j.fishres.2018.03.015

Koie M. (1993), Aspects of the life cycle and morphology of Hysterothylaciumaduncum(Rudolphi,1802) (Nematoda, Ascaridoidea, Anisakidae), Canadian Journal of Zoology, 71:1289-1296. https://doi.org/10.1139/z93-178

Lafferty K. D.,Holt R. D. (2003), How should environmental stress affect the population dynamics of disease, Ecology Letters, 6(7):654-664. https://doi.org/10.1046/j.1461-0248.2003.00480.x

Larsen G., Hemmingsen W., MacKenzie K., Lysne D. A. (1997), A population study of cod, Gadus morhua L., in northern Norway using otolith structure and parasite tags, Fisheries Research 32:13-20. https://doi.org/10.1016/S0165-7836(97)00040-4

Lester R.,J.,G., (2010), Review of methods for estimating mortality due to parasites in wild fish populations, Helgoland Marine Research 37:5364. 
Luque, J. L., Poulin, R. (2008), Linking ecology with parasite diversity in Neotropical fishes, Journal of Fish Biology, 72:189-204 https://doi.org/10.1111/j.1095-8649.2007.01695.x

MacKenzie K., Abaunza, P. (1998), Parasites as biological tags for stock discrimination of marine fish: a guide to procedures and methods, Fisheries Research 38:45-56. https://doi.org/10.1016/S01657836(98)00116-7

Marcogliese D.J. (1995), The role of zooplankton in the transmission of helminth parasites to fish. Reviews in Fish Biology and Fisheries 5(3): 336-371.https://doi.org/10.1007/BF00043006

Ozer A., Korniychuk Y.M., Öztürk T., Yukhno V. (2015), Comparative study on parasite fauna of the whiting Merlangius merlangus in the northern and southern zones of the Black Sea, Journal ofFisheries and Aquatic Sciences 15 (2):283-291 DOI:10.1007 / s00436-017-5550-7

Pedersen A.B., Fenton A. (2006), Emphasizing the ecology in parasite community ecology, Trendsin Ecology \& Evolution, 22 (3): 133-139. DOI:10.1016 / j.tree.2006.11.005

Radu G., Nicolaev S., Anton E., Maximov V. (2013), Evolution of Romanian Marine Fisheries Following EU Accession. Cercetari Marine/Recherches Marines, 43: 249-267.

Radu Gh., Radu E., Nicolaev S, Anton E. (2008), Atlas of the main species

Of fish from the Black Sea, National Institute for Marine Research and Development “Grigore Antipa”, Publishing VIROM,Constanta, 293p.

Santos, M. J., Saraiva, A., Cruz, C., Eiras, J. C., Hermida, M., Ventura, C.,Soares, J. P. (2009), Use of parasites as biological tags in stock identification of the black scabbardfish, Aphanopus carbo Lowe, 1839 (Osteichthyes: Trichiuridae) from Portuguese waters, Scientia Marina,73: 55-62. https://doi.org/10.3989/scimar.2009.73s2055

Sindermann C. (1987), Effects of parasites on fish populations: practical considerations, International Journal for Parasitology, 17:371-382p. DOI:10.1016 /0020-7519 (87) 90112-3 